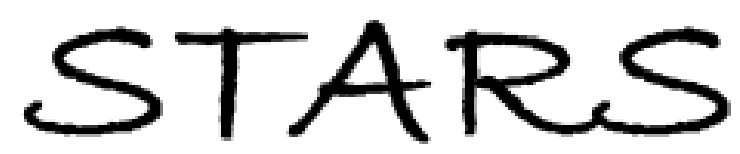

University of Central Florida

STARS

7-25-2016

\title{
Applicability and usefulness of the stakeholder strategy matrix for festival management
}

\author{
Mathilda Van Niekerk \\ University of Central Florida, mathilda.vanniekerk@ucf.edu
}

Part of the Hospitality Administration and Management Commons, and the Tourism and Travel

\section{Commons}

Find similar works at: https://stars.library.ucf.edu/rosenscholar

University of Central Florida Libraries http://library.ucf.edu

This Paper is brought to you for free and open access by the Rosen College of Hospitality Management at STARS. It has been accepted for inclusion in Rosen Faculty Scholarship and Creative Works by an authorized administrator of STARS. For more information, please contact STARS@ucf.edu.

\section{Original Citation}

Van Niekerk, M. (2016). Applicability and usefulness of the stakeholder strategy matrix for festival management. Event Management, 20(2), 165-179.

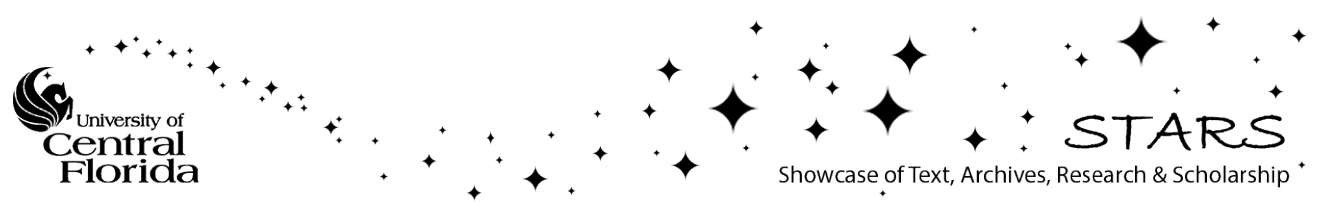




\title{
THE APPLICABILITY AND USEFULNESS OF THE STAKEHOLDER STRATEGY MATRIX FOR FESTIVAL MANAGEMENT
}

\author{
MATHILDA VAN NIEKERK \\ Tourism, Events \& Attractions Department, Rosen College of Hospitality Management, \\ University of Central Florida, Orlando, FL, USA
}

\begin{abstract}
This article examines the applicability and usefulness of the stakeholder strategy matrix in the context of festival management. An extensive literature review gave rise to the development of an online survey. Data for the study were collected from festival managers in the US. This empirical study indicated that internal and external festival stakeholders differ from each other in significant ways, and that different management strategies should be used to manage them. The stakeholder strategy matrix appears to be more effective for the management of internal festival stakeholders and the least effective for managing external festival stakeholders. Based on the results of the study, it can be postulated that the stakeholder strategy matrix can be applied effectively towards managing festival stakeholders and may provide useful management strategies for festival managers when managing their internal and external stakeholders. This is one of the first studies to be conducted in this area, and as such it contributes to the body of knowledge on management strategies for internal and external festival stakeholders.
\end{abstract}

Key words: Stakeholder theory; Stakeholder strategy matrix; Festivals; Events; Festival management

\section{Introduction}

Festivals are not static events and certainly do not function in isolation. Instead, festivals constantly develop in the context of interaction with people in their internal and external environments. These people are, of course, known as the festivals' stakeholders. A stakeholder is, furthermore, someone who can affect the festival or who is affected by the festival, or who plays an important role in terms of the survival of the festival (Polonsky \& Scott, 2005). Freeman
(2010) propounds that the ultimate purpose of an organization ("organization” here includes festivals) is to coordinate their stakeholders and their interests within the organization, so that the organization can become more sustainable and successful over the long term. The essential premise of the stakeholder theory is that the organization should have a relationship with its stakeholders in order for it to be successful. Freeman (2010) particularly emphasizes the importance of focusing on the nature and interests of stakeholders and taking the necessary (and 
appropriate) managerial decision to accommodate them. However, previous studies that have been conducted in this area of research tended to focus on the outcomes of addressing the different stakeholders rather than looking at different stakeholder management strategies that can be applied towards managing stakeholders (Berman, Wicks, Kotha, \& Jones, 1999; Minoja, 2012).

It is important to understand the link between the correct management strategy that is applied when dealing with the stakeholders, and the outcome of the selected strategy (Polonsky \& Scott, 2005). It is possible that poor outcomes may be a reflection of an incorrect choice of stakeholder management strategy. Freeman (1984) developed a stakeholder strategy matrix that assists organizations towards applying a number of generic management strategies when managing their stakeholders' interests. Comprising of four quadrants, the stakeholder strategy matrix divides stakeholders based on their ability to cooperate and threaten the organization; it also suggests apposite strategies for managing stakeholders. Other researchers such as Polonsky (1996), Polonsky and Scott (2005), and Savage, Nix, Whitehead, and Blair (1991) have tested the stakeholder strategy matrix as a potentially useful tool that can explain the interest of various stakeholders. It also provides managers with guidance regarding the use of different strategies that can be used to manage relationships and improve organizational performance. However, the applicability and usefulness of the stakeholder strategy matrix in the context of festivals and events has not been fully examined before. In other words, previous studies have not empirically investigated whether festival stakeholders' cooperative and threatening potential are significantly different from each other, or whether there are differences between the cooperative and threatening potential of internal and external stakeholders. Given this gap in the literature, the current article aims to examine whether the stakeholder strategy matrix provides useful guidance for festival managers when dealing with internal and external stakeholders.

\section{Stakeholder Theory}

The stakeholder theory suggests that by addressing the interest of stakeholders, an organization will be more sustainable and perform better (Freeman, 2010; Freeman, Wicks, \& Parmar, 2004). Although several previous tourism and festival studies (Garrod, Fyall, Leask, \& Reid, 2012; Getz, Andersson, \& Larson, 2007; Karlsen \& Nordstrom, 2009; Presenza \& Iocca, 2012) have introduced the stakeholder theory with the work of Freeman, the foundation of the theory can be traced back to the Stanford Research Institute (SRI) in 1963 (Freeman, 1984). The term stakeholder was originally meant to generalize the notion of stockholders; these were seen as the only group to whom management needed to respond. According to the stakeholder theory, organizations' stakeholders included the owners, customers, suppliers, society, lenders, and the employees of that organization. Freeman (2010) states that in 1965, Ansoff and Stewart continued the work of the SRI; the author adds that if the executives of the organization do not understand the needs and the concerns of these stakeholder groups, it would be impossible for the organization to formulate corporate objectives that are well supported. Unsupported objectives by the stakeholders would have a negative effect on the organization and would threaten its survival.

Ansoff (1965), however, rejected the stakeholder theory in his research on the basis that the responsibilities and the objectives of the organization are not anonymous, but that they have been seen as similar in the stakeholder theory (Ansoff, 1965; Freeman, 2010). Supporters of the stakeholder theory, however, maintained that the objective of the organization is to balance the conflict between the various stakeholders within the firm (managers, employees, stockholders, suppliers, and vendors) by separating the economic side (making profit) from the social side (responsibility to stakeholders).

In the mid-1970s, Ackoff and Churchman (Sethi, 1971) rediscovered the stakeholder theory. The social movements that characterized the 1960s, such as the civil rights and antiwar demonstrations, the rise of consumerism, and the women's rights movement all served as catalysts for organizations to rethink their role in society (Freeman, 2010; Sethi, 1971). The focus within organizations therefore partially shifted from the satisfaction of the owner towards the community, the employees, and the public. Dill (1975) has noted that the concept of stakeholder influence shifted towards stakeholder participation. He viewed it as part of the broader organizational social audit 
whose role it was to analyze the organization's actions in terms of social cost and social benefits. Similarly, Clarkson (1995) has pointed out that the survival of the organization depends, among other things, on its ability to satisfy its stakeholders.

The stakeholder theory therefore focuses on the purpose of the firm and reflects on the responsibility of management towards its stakeholders (Freeman et al., 2004). However, the question remains: Who are the stakeholders? In 1963, The Stanford Research Institute defined a stakeholder as those groups that support the organization and without whose support the organization would not be able to exist (Freeman, 2010). According to Pajunen (2006), stakeholders are those groups that can make a difference in the organization's success or failure. For Sautter and Leisen (1999), a stakeholder can be an individual or a group who has a legitimate interest in the organization's activities and has the power to affect the organization's performance and/or has a stake in its performance. Although common aspects can be identified in the above definitions, Freeman's (1984) definition will be used for the purpose of the current study. He defines stakeholders as: "any group or individual who can affect or is affected by the achievement of the organizations objectives" (p. 4).

Several tourism and festival studies have used the stakeholder theory in their research. Most of this research tended to focus on the identification of destination and festival stakeholders (Garrod et al., 2012; Getz \& Andersson, 2009; Getz et al., 2007; Larson, 2002; Reid \& Arcodia, 2007; Sheehan \& Ritchie, 2005; van Niekerk, 2014) while others focused on the roles and functions of these stakeholders (Anuar, Ahmad, Jusoh, \& Hussain, 2012; Getz et al., 2007; Karlsen \& Nordstrom, 2009). Very few studies have, however, explored the management strategies of destination and festival stakeholders. Before developing and implementing the correct stakeholder management strategies, the stakeholders should be clearly defined, identified, and grouped. Getz (2010) refers to festival stakeholders as: "those persons or groups who can influence the organization, or are influenced by it” (p. 2). Stakeholders have a stake in the event or festival and its outcomes, and these include the event production, sponsors, grant givers, community representative, and anyone else impacted by the event. Other studies have added the artists and their booking agents, employees, organizers and attendees, government agencies, media, suppliers, police and public services, tourism traders, venues and facilities, and volunteers to the stakeholder list (Andersson \& Getz, 2008; Getz et al., 2007; Karlsen \& Nordstrom, 2009; Larson, 2002; Presenza \& Iocca 2012; van Niekerk \& Coetzee, 2011).

Once the stakeholders have been identified, it becomes possible to group them together into groups with shared attributes. Some authors group stakeholders as either primary or secondary (Carroll, 1989; Clarkson, 1995; Freeman, 2010; Sheehan \& Ritchie, 2005). Primary stakeholders are classified as those stakeholders who have a formal or an official contract relationship with the organization or festival and without whom the organization or festival will not be able to survive (Clarkson, 1995; Freeman, 2010). On the other hand, secondary stakeholders can be seen as those who will have an affect or can be affected by the organization or festival, but who are not engaging in transactions with the organization or festival and are not essential to its survival (Clarkson, 1995; Freeman, 2010). Sheehan and Ritchie (2005) further note that stakeholders can be grouped based on issues such as (1) the power of the stakeholder, (2) the urgency of the relationship, as well as (3) the legitimacy of the stakeholder. The festival's dependency on the stakeholder should also be considered as it can influence the choice of the management strategy.

Garrod et al. (2012) group stakeholders into five groups, namely local community, investors, suppliers, customers, and employees. Other researchers have developed models with different numbers and other combinations of stakeholder groupings (Freeman et al., 2004; Getz et al., 2007; Presenza \& Iocca, 2012; Sheehan \& Ritchie, 2005). These authors have attempted to group stakeholders in their research on tourism and festival studies, but no consensus has been reached among them as to how exactly festival stakeholders should be grouped. It seems necessary to develop a model to address this gap. For the purpose of this study, festival stakeholders are, however, divided into eight groups as identified by Polonsky and Scott (2005). The reason why Polonsky and Scott's (2005) grouping is used is because they are among the few researchers who have developed and tested the stakeholder strategy matrix in different areas, which facilitates comparisons between studies. Their grouping of stakeholders entails: competitors, customers, 
employees, government, owners/shareholders, special interest groups, suppliers, and top management.

The identification and differentiation of stakeholders is crucial for the development and implementation of the appropriate management strategies (Anuar et al., 2012; Getz, 2010). In other words, managers should understand the nature of the link between the management strategies that are applied and the outcomes achieved (Polonsky \& Scott, 2005). Poor outcomes might be the result of applying an incorrect management strategy, or the lack of the implementation of an appropriate strategy in a given situation. A tool to assist festival managers in identifying the correct management strategy when dealing with stakeholders is called the stakeholder strategy matrix, which was developed in the management sciences. Based on the above discussion, the next section will focus on the stakeholder strategy matrix and its applicability and usefulness to festival management.

\section{Stakeholder Strategy Matrix}

A stakeholder strategy matrix has been proposed by Freeman (2010); this matrix aims to assist organizations in applying general management strategies when addressing their internal and external stakeholder interests. These generic strategies can be applied in various circumstances, and by implementing the correct strategies the organizational learning and organizational legitimacy should improve (Polonsky \& Scott, 2005). It is believed that organizations can use the stakeholder strategy matrix and, based on their evaluation, they can determine management strategies applicable to a specific stakeholder depending on its position within the two-dimensional matrix model. Polonsky and Scott (2005) have synthesized the 13 generic management strategies as identified by Freeman $(1984,2010)$ and Savage et al. (1991) in terms of their applicability to the different quadrants (Table 1) to assist with stakeholder management. Freeman (2010) identifies certain generic management strategies that can be used to address the interest of the organization's internal and external stakeholders based on their ability to either cooperate or threaten the organizations outcomes. As shown in Table 1 and Figure 1, consisting out of four quadrants, the stakeholder strategy matrix divides stakeholders based on their ability to threaten and cooperate with the organization.

Table 1

Applicable Generic Strategies

Dependent Variable

$\begin{array}{cccc}\text { Swing } & \text { Defensive }^{\mathrm{a}} & \text { Offensive }^{\mathrm{a}} & \text { Hold }^{\mathrm{a}} \\ \text { Change } & \text { Defend } & \text { Exploit } & \text { Hold } \\ \text { High }^{\mathrm{b}} / \text { High }^{\mathrm{c}} & \text { High }^{\mathrm{b}} / \text { Low }^{\mathrm{c}} & \text { Low }^{\mathrm{b}} / \text { High }^{\mathrm{c}} & \text { Low }^{\mathrm{b}} / \text { Low }^{\mathrm{c}}\end{array}$

1. Modify the circumstance in which the festival and this stakeholder

$\mathrm{X}$ interact

2. Change the formal or informal rules under which this stakeholder operates

3. Refocus this stakeholder's objectives

4. Informally collaborate with this stakeholder when establishing policy for the festival

5. Reinforce this stakeholder's beliefs about the festival

6. Include this stakeholder when developing strategy

7. Modify this stakeholder belief about the festival

8. Change festivals organizational behavior to address this stakeholder's concerns

9. Continue with existing activities

10. Reduce reliance on this stakeholder

11. Monitor this stakeholder for change in their beliefs/behavior/attitudes

12. Minimize the possibility of this stakeholder-firm relationship changing in any way

13. Link this stakeholder to the firm's wider objective

\section{$\mathrm{x}$}

$\begin{array}{ll}\mathrm{x} & \mathrm{X}\end{array}$

$\mathrm{x}$

$\mathrm{X}$

$\begin{array}{lll} & \mathrm{X} & \mathrm{X} \\ \mathrm{X} & \mathrm{X} & \mathrm{X} \\ \mathrm{X} & & \\ \mathrm{x} & \mathrm{X} & \\ & & \mathrm{X}\end{array}$

Source: Developed from Freeman (2010) and Savage et al. (1991) and synthesis by Polonsky and Scott (2005).

${ }^{a}$ Management strategy.

${ }^{\mathrm{b}}$ Threatening ability.

'Coopertive ability. 


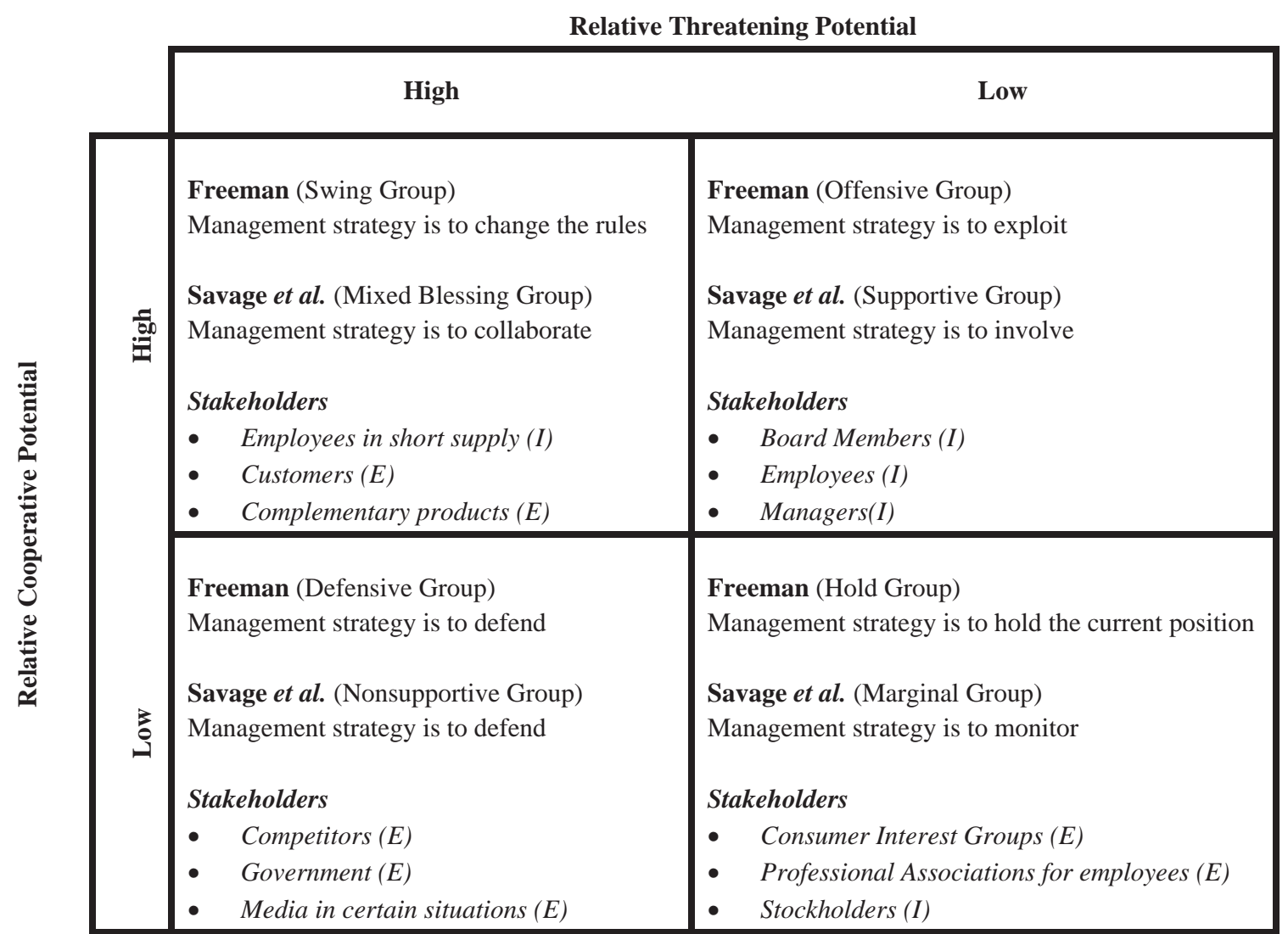

Figure 1. Stakeholder strategy matrix model. Source: Adapted from Freeman (1984) and Savage et al. (1991). I = internal stakeholder; $\mathrm{E}$ = external stakeholder.

The purpose of this study is to determine whether the stakeholder strategy matrix can be applied and used for the management of festival stakeholders. Before the applicability and usefulness of the stakeholder strategy matrix can therefore be determined for festivals, one first needs to establish whether festival stakeholders' cooperative and threatening potential are different from each other. Thereafter, one would need to determine is the cooperative and threatening potential of the internal and external stakeholders towards the festival.

The following hypotheses have therefore been developed:

H1: The cooperative and threatening potential of all festival stakeholders differs in significant ways.
H2: The threatening potential of internal and external stakeholders is significantly different from each other.

H3: The cooperative potential of internal and external stakeholders is significantly different from each other.

Depending on the positioning within the matrix, each category provides an appropriate management strategy that should be applied when dealing with the stakeholders.

\section{Quadrant 1: High Threating Potential and High Cooperative Potential}

Stakeholders in this group are referred to as “swing” stakeholders (Freeman, 1984). They play a major role in the organization (Savage et al., 1991). 
These stakeholders can either assist the organization or they may decide to hinder the organization and its activities. The management strategy suggested for this group is that one should "seek to change or influence the rules that govern the interaction" (Polonsky 1996, p. 217). Savage et al. (1991) refer to these stakeholders as the "mixed blessing group" and identify the "collaborate management strategy" as the best strategy to use when engaging with this group (p. 65). Collaboration should help one to maximize their cooperative potential and also to minimize their threatening potential. Internal stakeholders for this group would include employees that are in short supply and external stakeholders would be the customers, or complementary products or services supplied.

\section{Quadrant 2: Low Threating Potential and High Cooperative Potential}

The stakeholders in this group are defined by Freeman (1984) as the "offensive group," or the "supportive group” by Savage et al. (1991). The management strategy suggested for this group is to involve the stakeholders in relevant issues, thus maximizing on their cooperative potential. In a well-managed organization, the following internal stakeholders should form part of this category: board of trustees, staff employees, managers, and parent company. External stakeholders in this category include suppliers, service providers, and nonprofit community organizations.

\section{Quadrant 3: Low Cooperative and High Threatening Potential}

According to Freeman (1984), the stakeholders in this group are referred to as "defensive stakeholders." They are the most distressing type for any manager and organization, according to Savage et al. (1991). The management strategy suggested when dealing with these stakeholders is to defend the organization against them. This group's "nonsupportive" potential has led Savage et al. (1991) to believe that the best strategy to manage them would be to defend the organization against them. Typically, the stakeholders here would include competitors, employee unions, federal government, and sometimes the media.

\section{Quadrant 4: Low Cooperative and Low Threatening Potential}

The stakeholders in this group are not highly cooperative or highly threatening, and although they might have a stake in the organization, they are not generally concerned about many of the issues. The stakeholders in this group are referred to as the "holding stakeholders" (Freeman, 1984). In managing these stakeholders, the organization should maintain its current position and monitor their position for any changes that may be taking place. Savage et al. (1991) similarly identify this group as the "marginal group" and the management strategy proposed by these authors is likewise to monitoring. For a medium- to large-sized organization, the stakeholders in this group would be consumer interest groups, professional associations for employees (external), and stockholders (internal).

Following this stakeholder strategy matrix, festival managers should be guided by the position of their internal and external festival stakeholders within the matrix. This will help them to determine their relationship with the stakeholders as well as the most appropriate management strategy to use. The matrix has been utilized by various researchers as a useful tool for identifying individual stakeholders' interests and providing guidance in terms of managing them (Freeman, 1984; Polonsky, 1996; Polonsky \& Scott, 2005). However, few empirical studies have tested the applicability of the stakeholder strategy matrix in different study fields such as festivals.

H4: The stakeholder strategy matrix is more useful and applicable for internal festival stakeholders than external festival stakeholders.

Based on previous studies, this section has developed a theoretical framework and proposed research hypotheses. The next section will explain the methodology that was used for this study.

\section{Methodology}

This study made use of the deductive research approach, which is associated with the positivism paradigm (Gill \& Johnson, 2010; Gray, 2009). The deductive approach focuses on the existing 
theoretical knowledge. In this study, the stakeholder theory and the stakeholder strategy matrix were first reviewed. From here, the researcher proceeded to develop a theoretical framework and proposed hypotheses. This led to the development of the questionnaire that set out to test the stakeholder strategy matrix, as well as its usefulness and applicability in managing festival stakeholders in the US.

This study gathered primary data from festival managers across the US by means of an online questionnaire. The online-based questionnaire was primarily developed based on the research of Freeman (1984) and Polonsky and Scott (2005). The questionnaire consisted of 31 questions. Questions 1-9 were used to identify the different festival stakeholders. Questions 10-12 concerned the relationship of festival managers with their different stakeholders, and questions 12-14 investigated the different management approaches followed by the festival managers when managing festival stakeholders. Questions 15-16 looked at the influencing potential of festival stakeholders and questions 17-18 explored the communication used. Questions 19--aimed to determine the success factors of the festivals and questions 21-28 set out to address the characteristics of the different festivals. Questions 29-31 requested demographic aspects of festival managers. The questionnaire consisted of open- and closed-ended questions with a view to ensure that all possible answers were captured. A Likert scale was used throughout the questionnaire. The questionnaire was pilot tested with five local festival managers. Academic colleagues and Ph.D. students in this field also pretested the survey and provided feedback. The feedback that was received was then evaluated and incorporated into the survey with a view to improve its quality.

The target population of the study comprised festival managers in the US. However, there are no reliable lists of festivals and their managers available in the US. The researcher thus made use of an internet search, and contacted convention and tourism bureaus, friends, colleagues, and the Facebook pages of festival associations. In this manner, the researcher found 410 festivals and created a database with these festivals' names and the contact addresses of their managers. After finalizing the survey, an e-mail was sent out to the managers of those 410 festivals in the US, requesting them to complete the online questionnaire. The managers were also kindly asked to forward the invitation e-mail to other festival managers that they might know. A follow-up e-mail was sent out 2 weeks later to remind the participants of the survey. After a 6-week period, 57 festival managers completed the questionnaires. For the field of festival studies this number is acceptable as most studies that have been conducted on festivals tend to focus on a small sample size; conversely, studies are often case study oriented (Akintan, 2013; Getz, 2013). Andersson and Getz (2009), for instance, looked at festival ownership of 13 festivals in Sweden, while Karlsen and Nordstrom (2009) investigated stakeholder cooperation of three festivals in the Barents Region. A study by Getz et al. (2007) covers the roles of festival stakeholder in 13 festivals in Canada and Sweden, while Andersson and Getz (2008) explored the stakeholder management strategies of 14 live music festivals in Sweden. The study by Presenza and Iocca (2012) investigated the weight of festival stakeholders of 48 Italian music festivals. The current study is therefore one of a kind because it involves and researches so many festivals at the same time.

Informed consent was obtained from participants. Furthermore, the researcher avoided deception, harm, or risk to any participants and set out to ensure trust between the researcher and participants. All "unique identifiers" were removed from the electronic questionnaire with a view to ensure privacy to all respondents. The researcher followed all policies and procedures stipulated by the Institutional Research Board (IRB) of the University. An application was submitted to the IRB and the study, concept letter, and questionnaire were approved by the IRB. There were no unique identifiers used in this study and the participants were therefore entirely anonymous.

The online survey was managed through Qualtrics and data were then exported to SPSS 21 for statistical analysis. This study sought to develop both descriptive and inferential statistics. The Importance-Performance Analysis (IPA) was used to graphically display the mean ratings of all stakeholders' threatening and cooperative potential on an easily interpreted two-dimensional graph (Martilla \& James, 1977). The stakeholder strategy matrix 
model was used to analyze the applicability and usefulness of the matrix in the management of festival stakeholders in greater detail.

All possible measures were taken into account in the design of the questionnaire with a view to ensure face validity, content validity, criterion validity, and concurrent validity. It is known that the greatest threat by far in terms of online questionnaire validity is that of the sampling error, because certain demographic segments of the population might be underrepresented due to the availability of Internet access. It was, however, presumed that most festivals that are positioned in the US would have a website or would at least have access to the Internet. In designing the measuring instrument, the researcher took extra care to ensure the interrater reliability of the questionnaire so that similar people would yield similar results. Internal consistency was added to the questionnaire where different questions were asked to test the same construct, and a Cronbach's alpha score of 0.898 was reported. The next section reports the findings of the empirical research and presents an analysis and discussion of these findings.

\section{Study Results and Discussion}

\section{Demographic Information}

As presented in Table 2, about $67 \%$ of the respondents have fairly extensive experience (more than 5 years) in the events and festival industries. In terms of demographics, about $89 \%$ of the respondents were females and only $11 \%$ were males. Although this is not an equal distribution in terms of gender, the results can be understood in light of the fact that there are a much higher percentage of women within the event and festival industry. These results are similar to findings from other studies (Goldblatt, 2000, 2002). Respondents were fairly advanced in terms of number of years of experience, which also can be explained when looking at the age of the festivals and the fact that many are community focused; festival organizers are often living within these communities. According to the study findings, the festival managers have a higher gross annual income than that of the national average personal income of \$32,184 (US Census Bureau, 2012) and vary similar to the mean average of $\$ 49,830$ for meeting, convention, and
Table 2

Demographic Information

\begin{tabular}{lr}
\hline Festival management experience (years) & \\
$1-5$ years & $33 \%$ \\
$6-10$ years & $33 \%$ \\
$11-15$ years & $17 \%$ \\
$16-20$ years & $6 \%$ \\
$20+$ years & $11 \%$ \\
Gender & \\
Male & $11 \%$ \\
Female & $89 \%$ \\
Ages of festival managers & \\
$25-34$ years & $11 \%$ \\
$45-54$ years & $32 \%$ \\
$55-64$ years & $37 \%$ \\
$65-75$ years & $16 \%$ \\
$75+$ years & $4 \%$ \\
Level of education & \\
High school & $6 \%$ \\
Associate degree & $11 \%$ \\
Bachelor & $44 \%$ \\
Masters & $33 \%$ \\
Other, specify & $6 \%$ \\
Personal gross annual income & \\
Under $\$ 10,000$ & $6 \%$ \\
\$25,000-\$34,999 & $13 \%$ \\
\$35,000-\$49,999 & $13 \%$ \\
\$50,000-\$74,999 & $38 \%$ \\
\$75,000-\$99,999 & $19 \%$ \\
\$100,000-\$149,999 & $6 \%$ \\
Over $\$ 150,000$ & $5 \%$ \\
\hline
\end{tabular}

event planners in the US (US Bureau of Labor Statistics, 2014). These results can be ascribed to the levels of the respondents' education (33\% had Master's degrees). This percentage is higher than the national average where the median is a Bachelor's degree (US Bureau of Labor Statistics, 2014).

\section{Festival Stakeholders and Their Threatening and Cooperative Potential (Direct Measure vs. Theoretical Construct)}

Table 3 presents the identification of the different stakeholders. According to study results, few festival stakeholders (29\%) see their competitors as a stakeholder in their festivals. Evaluating these results against the definition of a festival stakeholder: "someone that is influenced or which can have an influence on the organization" (Freeman, 2010, p. 31), it seems that festival managers fail to recognize the potential of viewing competitors as stakeholders. They should rather aim to understand that competitors can indeed have a major influence 
Table 3

Identification of Different Stakeholders

\begin{tabular}{lcc}
\hline Festival Stakeholders & Yes & No \\
\hline Customers & $76 \%$ & $24 \%$ \\
Competitors & $29 \%$ & $71 \%$ \\
Employees & $88 \%$ & $12 \%$ \\
Government/government agencies & $75 \%$ & $25 \%$ \\
Owners/shareholders & $86 \%$ & $14 \%$ \\
Special interest groups & $46 \%$ & $54 \%$ \\
Suppliers & $63 \%$ & $37 \%$ \\
Senior managers & $84 \%$ & $16 \%$ \\
\hline
\end{tabular}

on their festivals and therefore they should be seen as important festival stakeholders.

Festival organizers were asked to rate the threatening and cooperative potential of various stakeholders on a 7-point Likert scale where 7 was the most threatening/cooperative and 1 was the least. For example, if festival managers agreed very highly or extremely highly, or if they indicated very low or extremely low when asked if the stakeholders had the potential to threaten/cooperate with the festival, the stakeholder was classified as "high" or "low" respectively within the stakeholder strategy matrix. It can be seen in Table 4 (theoretical construct) that Senior managers, Owners/shareholders, Customers, and Employees received this highest scores on both threatening and cooperative potential.

As presented in Table 5, a paired $t$ test was employed to determine if there was a significant difference between the cooperative and threatening potential of the different stakeholders (H1). Secondly, the threatening potential of internal and external stakeholders was comparatively examined
(H2), and thirdly, the cooperative potential of internal and external stakeholders was measured (H3). It was found that all stakeholders were significantly different from each other at a 95\% confidence level. The results therefore support hypothesis H1, H2, and $\mathrm{H} 3$.

H1: The cooperative and threatening potential of all festival stakeholders differs in significant ways. (Supported).

H2: The threatening potential of internal and external stakeholders is significantly different from each other (Supported).

H3: The cooperative potential of internal and external stakeholders is significantly different from each other (Supported).

Festival organizers were asked to identify their most preferred strategy for managing stakeholders (direct measure). As presented in Table 6, the most preferred management strategies used by festival managers were collaboration (62), involvement (60), monitoring (24), and the defend (9) strategy. Collaboration as a management strategy was mostly used for senior management and government. This finding is different from the results of a study by Savage et al. (1991). Involvement as a management strategy was used for customers and suppliers. Suppliers fell into the same quadrant in the study by Savage et al. (1991), but customers were in the collaborative matrix. Monitoring as a management strategy was used for competitors, which is again different from the results found in Savage et al. (1991). Defending as a management strategy was mostly used in the instance of

Table 4

Most Preferred Management Strategies (Theoretical Construct)

\begin{tabular}{lccl}
\hline Festival Stakeholders & $\begin{array}{c}\text { Threatening } \\
\text { Potential Mean }\end{array}$ & $\begin{array}{c}\text { Cooperative } \\
\text { Potential Mean }\end{array}$ & Strategy \\
\hline Competitors & 3.79 & 4.20 & Monitor \\
Customers & 5.54 & 5.22 & Collaborate \\
Employees & 5.45 & 5.76 & Collaborate \\
Government/government agencies & 4.83 & 4.86 & Monitor \\
Owners/shareholders & 5.82 & 5.50 & Collaborate \\
Special interest groups & 4.68 & 5.05 & Monitor \\
Suppliers & 4.88 & 5.22 & Involve \\
Senior managers & 5.90 & 5.89 & Collaborate \\
Grand mean & $\mathbf{5 . 1 1}$ & $\mathbf{5 . 2 1}$ & \\
\hline
\end{tabular}


government, which is similar to those results found by Savage et al. (1991).

\section{Comparison Between Festival Managers \\ Preferred Strategies to Theoretically \\ Derived Strategies From Construct}

The next part of the analysis set out to evaluate the preferred management strategy as identified from the direct measure with those identified by the management strategy compiled from the theoretical construct, and to determine whether there were any discrepancies between the two. The similarities and differences can be seen in Table 7. There is a difference in management strategies used for customers, government, and special interest groups, and also between what festival managers directly indicated as preferred strategies and the strategies as compiled from the theoretical construct. It is interesting to see that the management strategies only differ with regard to the external stakeholders, while the strategies are the same for managing internal stakeholders. Study results therefore support H4.

H4: The stakeholder strategy matrix is more useful and applicable for internal festival stakeholders than external festival stakeholders (Supported).

It seems as if festival stakeholders use a collaborative strategy for most of their stakeholders (direct measure), which might not be the most effective strategy. They would rather need to develop more effective management strategies for stakeholders. Although the participants indicated that they involve their customers, a better strategy would be to actually collaborate with customers-as found by Savage et al. (1991). In terms of government as a stakeholder, results indicated a collaborative approach, but an involvement or monitoring management strategy might be more relevant in view of findings from the literature. Special interest groups were not identified as having a significant threatening or cooperative potential; also, the level of influence was indicated as very low. The question should be asked whether festival managers are indeed conscious of the power of special interest groups such as Greenpeace and similar organizations. The discrepancies should, however, be further 
Table 6

Most Preferred Management Strategies (Direct Measure)

\begin{tabular}{lccccc}
\hline Festival Stakeholders & Collaborate & Involve & Defend & Monitor & Total \\
\hline Competitors & 3 & 1 & & $13^{\mathrm{a}}$ & 17 \\
Customers & 4 & $16^{\mathrm{a}}$ & & 1 & 21 \\
Employees & $9^{\mathrm{a}}$ & $9^{\mathrm{a}}$ & & & 18 \\
Government & $10^{\mathrm{a}}$ & 9 & 9 & 1 & 29 \\
Owners/shareholders & $9^{\mathrm{a}}$ & 5 & & 2 & 16 \\
Special interest groups & $7^{\mathrm{a}}$ & 5 & & 5 & 17 \\
Suppliers & 9 & $10^{\mathrm{a}}$ & & 2 & 21 \\
Senior management & $11^{\mathrm{a}}$ & 5 & & & 16 \\
Total & 62 & 60 & 9 & 24 & 155 \\
\hline andicates the most preferred & & & & &
\end{tabular}

andicates the most preferred strategy.

investigated. It should nonetheless be appreciated that the greater the number of stakeholders that fall within the collaboration quadrant, the greater the pressure would be on the festival manager to please everyone. The next section of the results indicates the positioning of festival stakeholders within the stakeholder strategy matrix.

\section{Positioning of Festival Stakeholders Within the Stakeholder Strategy Matrix}

The grand mean (GM) scores obtained from the most preferred management strategies were determined from the theoretical construct as reported in Table 4. The GM for Relative Cooperative Potential was 5.21 and the GM for Relative Threatening Potential was 5.11. The IPA was then used to graphically display the GM ratings of all stakeholders threatening and cooperative potential; on an easily interpreted two-dimensional graph (Martilla \& James, 1977) (Fig. 2). Figure 2 graphically displays the quadrants into which the different festival stakeholders fall as well as and the management strategies that should be used to manage them.

According to the findings of the study, it was possible to add the different stakeholders to the stakeholder strategy matrix and to control the relevant management strategies (Fig. 2). The stakeholder strategy matrix appears to be a rather effective instrument when managing internal stakeholders but much less effective for managing external stakeholders. The stakeholder strategy matrix in general can therefore be accepted as useful and applicable to the management of festival stakeholders, except under one condition, and that is the inconsistency that was found in terms of the management strategies of government and special interest groups.

\section{Conclusions and Recommendations}

The overall aim of the research was to determine whether the stakeholder strategy matrix provides

Table 7

Comparison Between Festival Managers Preferred Strategies to Theoretically Derived Strategies From Construct

\begin{tabular}{lcll}
\hline Festival Stakeholders & External/Internal & Direct Measure & $\begin{array}{c}\text { Based on the } \\
\text { Theoretical Construct }\end{array}$ \\
\hline Competitors & External & Monitor & Monitor \\
Customers & External & Involve & Collaborate \\
Government & External & Collaborate & Monitor \\
Special interest groups & External & Collaborate & Monitor \\
Suppliers & External & Involve & Involve \\
Employees & Internal & Collaborate/involve & Collaborate \\
Owners/shareholders & Internal & Collaborate & Collaborate \\
Senior management & Internal & Collaborate & Collaborate \\
\hline
\end{tabular}


Relative Threatening Potential

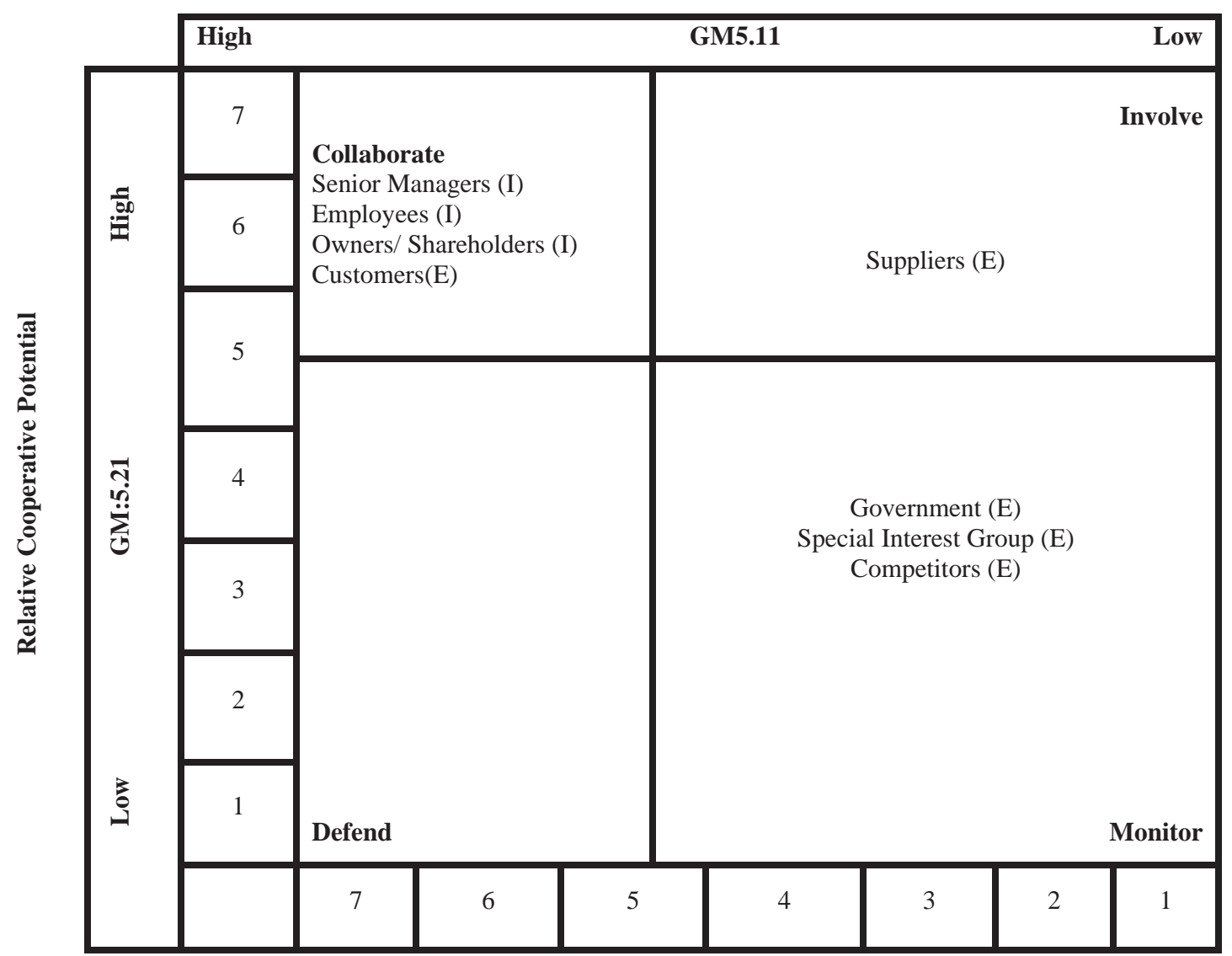

Figure 2. Positioning of festival stakeholders within the stakeholder strategy matrix (Source: Developed by author).

useful guidance for festival managers in dealing with internal and external stakeholders, and also to investigate the applicability and usefulness of the stakeholder strategy matrix in festival management in the US. Although the stakeholder theory was developed to identify the impact of the organization on the broader community (Freeman, 1984, 2010; Savage et al., 1991), this study has found that not much focus has been placed on the management of these stakeholders in various industries such as festivals and events (Polonsky \& Scott, 2005). The relationship between the festival organizers and their stakeholders is very likely to influence the sustainability and survival of the festival, and therefore festival managers should engage their stakeholders regularly (Garrod et al., 2012; Getz, 2005; Getz \& Andersson, 2009; Getz et al., 2007;
Larson, 2002; Reid \& Arcodia, 2007; Sheehan \& Ritchie, 2005). Different stakeholders have different threatening and cooperative potential that can have a major influence on the success and failure of the festival, and festival managers should take cognizance of this fact.

\section{Theoretical Implications}

The study contributes to the current body of literature as no previous research in the field of festivals studies could be found that set out to determine if there are significant differences between the cooperative and threatening potential of the different internal and external stakeholders. Very few studies also focused on how these internal and external festival stakeholders should be managed, and the 
findings of this research therefore establish guidelines for future research. This study's empirical data indicated that there is a significant difference between the cooperative and threatening potential of different festival stakeholders and these stakeholders should therefore be managed differently. The study also contributes theoretically by positioning festival stakeholders on the stakeholder strategy matrix and indicates the relevant management strategies applicable to them.

\section{Practical Implications}

The results indicated that the stakeholders with the most threatening potential were the senior managers, owners, and customers. Festival managers should keep this in mind when organizing and managing a festival; they should also ensure that they have the buy in of these important internal stakeholders. On the other side, the stakeholders with the most cooperative potential were the senior managers, employees, and owners/shareholders of the festival. Festival managers need to realize that the success of the festival is to a large degree dependent upon how they manage their internal team. These results differ from the positioning of stakeholders in a well-balance organization as indicated by Savage et al. (1991), where the senior managers and owners fall in the "involve" quadrant. The results for the customers are, however, the same. To ensure customer satisfaction, it is suggested that a customer satisfaction survey should be conducted with a view to measure their satisfaction levels and to make the necessary improvements to the festival for the subsequent year.

The most preferred management strategies identified by festival stakeholders were "collaboration" and "involvement"; these were also the preferred management strategies derived from the theoretical consideration. Following a collaborative and involvement strategy with most of the festival stakeholders can, however, cause a situation where it is very problematic and difficult for the festival managers to make a decision, as all stakeholders must be consulted every time. This can lead to delays in decision making and can have an effect on the overall efficiency of the festival. Festival managers should therefore be cautious to follow this management strategy for every instance. The preferred festival management strategies were also different from those found in the results of Savage et al. (1991) when dealing with government and competitors. Here, the defensive strategy was found as prominent, but within the festival context the external environment might not be as hostile as with large organizations.

It was interesting to find that the management strategies only differed in terms of external stakeholders, and not in terms of internal stakeholders. It is important to understand why a difference was found in terms of the management strategies of external stakeholders and not with the internal stakeholders. Festival managers should further develop applicable management relationship strategies with external stakeholders, and the value of external stakeholders should be assessed comprehensively. If this is not done, festival organizers may lose out on the availability of resources (government and special interest groups). Festival managers have only identified internal stakeholders as being cooperative and threatening; more focus should therefore be placed on the influence of external stakeholders. The stakeholder strategy matrix was in this sense most effective for the management of the internal stakeholders and least effective when managing the external stakeholders. The stakeholder strategy matrix in general can therefore be accepted as useful and applicable to the management of festival stakeholders. Practically speaking, festival managers can use these strategies to manage festival stakeholders more effectively and efficiently during engagement.

\section{Study Limitations and Future Research}

The 13 management strategies were grouped into the 4 management strategies as identified by Polonsky (1996). The study would have yielded better inferential statistics if the 13 management strategies were researched individually. Although this study was one of the first to transcend case study research within festivals, with more than 8,000 festivals taking place in the US on a yearly basis the results cannot be generalized. Some of the limitations in the study include the limited access that the researcher had to e-mail addresses of possible festival organizers. If the databases were more readily available the questionnaire could have been 
distributed to a larger sample size and better results could have been received.

Future studies should focus on why festival organizers are ambivalent regarding external stakeholders (this may be due to a lack of knowledge, trust, and resources). As no theoretical framework exists for the identification and differentiation of festival stakeholders, it is important that a theoretical framework should be developed in future studies. Lastly, more studies on festivals should be conducted specifically within the US, as currently there is very limited empirical research available.

\section{References}

Akintan, O. A. (2013). Traditional religious festivals and modernity: A case study of female-oriented cults' annual festivals in Ijebuland of South Western Nigeria. International Journal of Social Science and Education, 3(4), 1035-1046.

Andersson, T. D., \& Getz, D. (2008). Stakeholder management strategies of festivals. Journal of Convention \& Event Tourism, 9(3), 199-200.

Andersson, T. D., \& Getz, D. (2009). Festival ownership. Differences between public, nonprofit and private festivals in Sweden. Scandinavian Journal of Hospitality and Tourism, 9(2-3), 249-265.

Ansoff, I. H. (1965). Corporate strategy. New York: McGraw Hill.

Anuar, N. A., Ahmad, H., Jusoh, H., \& Hussain, M. Y. (2012). Understanding the role of stakeholders in the formation of tourist friendly destination concept. Journal of Management and Sustainability, 2(2), 69-74.

Berman, S., Wicks, A., Kotha, S., \& Jones, T. (1999). Does stakeholder orientation matter? The relationship between stakeholder management models and firm financial performance. Academy of Management Journal, 42(5), 488-506.

Carroll, A. B. (1989). Business and society: Ethics and stakeholder management. Cincinnati, $\mathrm{OH}$ : South-Western Publishing.

Clarkson, M. B. E. (1995). A stakeholder framework for analyzing and evaluating corporate social performance. Academy of Management Review, 20(1), 92-117.

Dill, W. (1975). Public participation in corporate planning: Strategic management in a kibitzer's world. Long Range Planning, 8(1), 57-63.

Freeman, R. E. (1984). Strategic management: A stakeholder approach. Boston, MA: Pitman.

Freeman, R. E. (2010). Strategic management: A stakeholder approach. Cambridge, UK: Cambridge University Press.

Freeman, R. E., Wicks, A. C., \& Parmar, B. (2004). Stakeholder theory and "the corporate objective revisited." Organization Science, 15(3), 364-369.
Garrod, B., Fyall, A., Leask, A., \& Reid, E. (2012). Engaging residents as stakeholders of the visitor attraction. Tourism Management, 33(5), 1159-1173.

Getz, D. (2005). Event management and event tourism (2nd ed.). New York: Cognizant Communication Corporation.

Getz, D. (2010). The nature and scope of festival studies. International Journal of Event Management Research, 5(1), 1-47.

Getz, D. (2013). Event tourism: Concepts, international case studies and research. New York: Cognizant Communication Corporation.

Getz, D., \& Andersson, T. (2009). Sustainable festivals: On becoming an institution. Event Management, 12(1), 1-17.

Getz, D., Andersson, T., \& Larson, M. (2007). Festival stakeholder roles: Concept and case studies. Event Management, 10(2-3), 103-122.

Gill, J., \& Johnson, P. (2010). Research methods for managers (4th ed.). Los Angeles, CA: Sage Publications Ltd.

Goldblatt, J. (2000). A future for event management: The analysis of major trends impacting the emerging profession. Sydney, Australia: Center for Event Management.

Goldblatt, J. (2002). Special events. Sydney, Australia: John Wiley.

Gray, D. E. (2009). Doing research in the real world. Los Angeles, CA: Sage Publications Ltd.

Karlsen, S., \& Nordstrom, C. S. (2009). Festivals in the Barents Region: Exploring festival stakeholders' cooperation. Scandinavian Journal of Hospitality and Tourism, 9(2-3), 130-145.

Larson, M. (2002). A political approach to relationship marketing: Case study of the Strosjoyran Festival. International Journal of Tourism Research, 4(2), 119-143.

Martilla, J. A., \& James, J. C. (1977). Importanceperformance analysis. Journal of Marketing, 41(1), 77-79.

Minoja, M. (2012). Stakeholder management theory, firm strategy, and ambidexterity. Journal Business Ethics, 109(1), 67-82.

Pajunen, K. (2006). Stakeholder influences in organizational survival. Journal of Management Studies, 43(6), 1261-1288.

Polonsky, M. J. (1996). Stakeholder management and the stakeholder strategy matrix: Potential strategic marketing tools. Journal of Market-Focused Management, 1(3), 209-229.

Polonsky, M. J., \& Scott, D. (2005). An empirical examination of the stakeholder strategy matrix. European Journal of Marketing, 39(9), 1199-1215.

Presenza, A., \& Iocca, S. (2012). The weight of stakeholders on festival management. The case of music festivals in Italy. Revista de Turismo y Patrimonia Cultural, 10(2), 25-35.

Reid, S., \& Arcodia, C. (2007). Understanding the role of stakeholder in event management. Journal of Sport and Tourism, 7(30), 20-22.

Sautter, E. T., \& Leisen, B. (1999). Managing stakeholders: A tourism planning model. Annals of Tourism Research, 26(2), 312-328. 
Savage, G. T., Nix, T. W., Whitehead, C. J., \& Blair, J. D. (1991). Strategies for assessing and managing organizational stakeholders. Academy of Management Executive, 5(2), 61-75.

Sethi, P. (1971). Up against the corporate wall. Englewood Cliffs, NJ: Prentice Hall.

Sheehan, L. R., \& Ritchie, J. R. B. (2005). Destination stakeholders: Exploring identity and salience. Annals of Tourism Research, 32(3), 711-734.

US Bureau of Labor Statistics. (2014). Occupational employment and wages, May 2012. Retrieved January, 2015, from http://www.bls.gov/oes/2012/may/oes_nat.htm
US Census Bureau. (2012). Income, expenditures, poverty \& wealth: Household income. Retrieved from https:// www.census.gov/library/publications/2011/compendia/ statab/131ed/income-expenditures-poverty-wealth.html

van Niekerk, M. (2014). Advocating community participation and integrated tourism development planning in local destinations. The case of South Africa. Journal of Destination Marketing \& Management, 3(2), 82-84.

van Niekerk, M., \& Coetzee, W. J. L. (2011). Utilizing the VICE model for the sustainable development of the Innibos Arts Festival. Journal of Hospitality Marketing \& Management, 20(3-4), 347-365. 